\title{
University Statistics of the United Kingdom, I919-20.1
}

$\mathrm{U}^{\mathrm{P}}$ $P$ to the year 1913-14 the Board of Education presented Annual Reports relating to university institutions in England and Wales in receipt of grants from the Board, but during the war this publication was discontinued. The volume now issued by the University Grants Committee marks the end of this five-years statistical holiday and the starting-point of a series of returns which, including, as they do, Scottish and Irish institutions in receipt of annual grants, and, as they presumably will, the Universities of Oxford and Cambridge and Trinity College, Dublin, will be far more comprehensive and significant than the pre-war returns published by the Board of Education. In eight comparative tables the public is provided with an abundant, but compact, store of information regarding university students of both sexes-whence they came, at what ages they were admitted, where they resided while pursuing their studies, the directions and durations of the courses they followed, the degrees and diplomas they gained-as well as complete statements of the grants made from the Treasury in each of the years $1913^{-14}$ to $1919^{-20}$. These are followed by notes and statistics and accounts concerning each institution separately. The notes are arranged under such heads as "Faculties and Subjects," "Extension Work," "Cost of Living and Hostel Facilities;" "Local Support." To the accounts of income and expenditure are appended expenditure schedules showing, separately for each department, the salaries of departmental heads, number and salaries of other teachers, cost of departmental and laboratory maintenance, etc. In future years income and expenditure are to be tabulated in comparative statements, and the cost per student of each institution is to be exhibited.

In the following paragraphs an attempt is made to indicate the more salient features of the information given in the collated statistics, and as these do not, as yet, include the students of Oxford, Cambridge, Trinity College, Dublin, the colleges at Durham, Guy's Hospital Medical School and some other schools of the University of London, and University College, Exeter, supplementary figures have been quoted from the I92 I edition of "The Yearbook of the Universities of the British Empire."

The number of full-time students, as given in the tables, was 37,081 , of whom 27 per cent. were women. The total for England alone, 20,486 , may be analysed topographically as follows, using round numbers : London institutions, 8000 ; North Midland group of universities-Birmingham, Leeds, Liverpool, Manchester, and Sheffield-with the Manchester College of Technology and Nottingham University College, 9300; Bristol University, with the Merchant Venturers'

1 Returns from Universities and University Colleges in Receipt of Treasury Grant, rgrg-20. Presented to Parliament by the University Grants Committee, April, 192t. (Cmd. 1263.) $3^{s .6}$. $\%$.
Technical College and the University Colleges of Southampton and Reading, 200o; Armstrong College and the College of Medicine, Newcastleupon-Tyne, r2oo. The totals for Wales, Scotland, and Ireland are 2473 , ro,992, and $3^{1} 30 \mathrm{re}-$ spectively. Compared with the returns for I9I $3^{-14}$, the numbers show increases of 83 , IOI, $3 \mathrm{I}$, and 76 per cent. in England, Wales, Scotland, and Ireland.

The results obtained by adding to the above figures statistics from the "Yearbook" may be stated thus: Oxford and Cambridge (including I Ioo women), II,800; London, Io, Ioo; North Midlands, 9300; the rest of England, 3400; Scotland and Wales, as above; Ireland, 4500; grand total of full-time students, 52,600 .

In any estimate of the significance of these statistics it is important to bear in mind that a very large number of persons engaged in studies of university grade are not accounted for either in the Grants Committee's tables-because they are not students of grant-receiving institutionsor in the "Universities' Yearbook" - because they do not belong to any university or university college. The institutions in the United Kingdom in which professional education of university grade is provided, although they are not organically connected with any university-theological colleges, training colleges, agricultural colleges, schools of mines, etc.-are numerous and important. Moreover, there are many students read. ing privately for the external degrees of the University of London, for the Bar, etc. On the other hand, it must be remembered, as pointed out in the Grants Committee's introduction to its returns, that there were in $1919-20$ nearly 17,000 full-time ex-Service students in attendance at university institutions in the United Kingdom (including II, 500 attending institutions in receipt of Treasury grants), and that when this special source of supply comes to an end there may be a substantial fall in the numbers.

Again, in any attempt to compare the number of university students in the United Kingdom with the corresponding number in, for example, the United States of America, where, in 1918 , there were 224,000 men and 151,000 women in 672 universities, colleges, and professional schools, it would be necessary to allow for several important differences in the conditions of higher education between the countries compared. For example, the work of the higher forms of many of our secondary schools corresponds with the earlier stages of the work done in many of the American colleges and collegiate departments of universities, and in many of the American institutions the enrolment of part-time students constitutes a very large proportion of the total number. In France the number of students in $1913-14$ in the University of Paris $(17,500)$ and the fifteen provincial universities amounted to 39,000 , but special branches of knowledge, tech- 
nology, and research were cultivated in numerous institutes and schools outside the universities.

A new and interesting feature of the returns is the classification of full-time students according to locality of home residence. The homes of approximately 60 per cent. were within 30 miles of the university, of 35 per cent. in other parts of the United Kingdom, of 4 per cent. ( ${ }^{390}$ ) within the British Empire overseas, of 2 per cent. (646) in foreign countries. The following institutions drew a noticeably high percentage of their students from beyond the 30-mile radius: University of Glasgow (5o per cent.), London Medical Schools (52), King's College Household and Social Science Department (58), Westfield College (6r), University Colleges of Galway (62), Dublin (71), Reading (72), Aberystwyth $\left(7^{8}\right)$. Those most frequented by students from outside the United. Kingdom are shown in the following list, wherein the first figure (A) represents the total number of such students, and the second (B) the number from foreign countries:

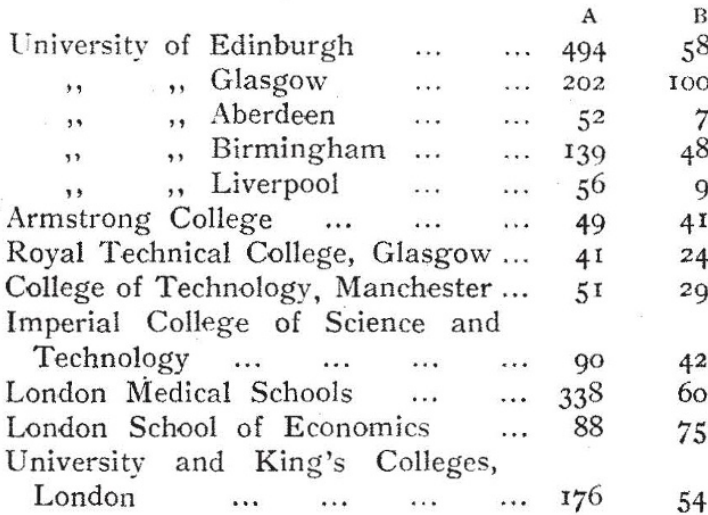

It will be noticed that a large proportion of the students from overseas in schools of technology and the London School of Economics were foreigners.

As regards Oxford and Cambridge and the other university institutions which find no place in these tables, the "Yearbook" does not indicate the sources from which their students are supplied, but the Universities Bureau of the British Empire a few months ago collected lists of students from other countries, both British and foreign, studying in the universities and university colleges of the United Kingdom, and it has permitted the publication of the following totals, taken from these lists, of students from $(a)$ the British Empire overseas, (b) foreign countries: Oxford (a) 307, (b) 308; Cambridge (a) 290, (b) 126 ; Dublin (a) 9r, (b) 2; Guy's Hospital Medical School (a) 195, (b) 26. The Oxford figures reflect the influence of the Rhodes Scholarships, which provide for the continuous residence at Oxford of 186 scholars drawn from the United States of America (two from each State), as well as from Canada and Newfoundland, Australasia, South Africa, the West Indies, and Malta. Apart from this, , however, Oxford No. 2696 , vOL. IO7] exerts on American students a powerful attraction, as is shown by an analysis of the $(b)$ figures given above. Separating students from the United States of America (c) from other foreign students (d), the totals for Oxford are (c) 217 , (d) 91; for Cambridge, (c) 34, (d) 92. Nearly all the students from overseas at Trinity College, Dublin, came from South Africa.

From the same source the following statistics have been compiled: Students from Asia, 1228; Africa, ro46; Europe, 703; America and the West Indies, 676; the Pacific (Australasia), 282. The countries contributing most largely to these totals are listed below with the distribution of the students to London (a), Oxford and Cambridge (b), Edinburgh $(c)$, and Glasgow $(d)$ :-

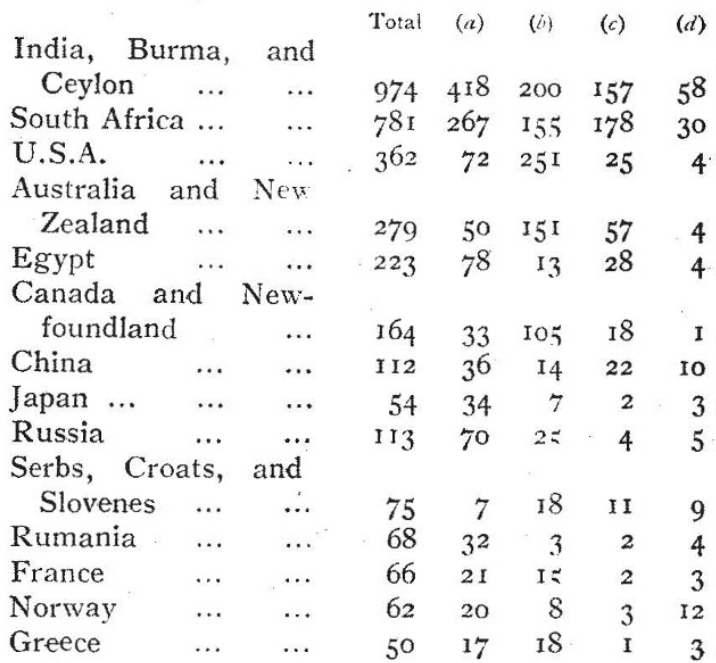

Of the students from South Africa, 229 were at the London Medical Schools, and 32 at Aberdeen. Of those from Egypt, 5I were at the London Medical Schools, $4 \mathrm{I}$ at Manchester and Liverpool, and 39 (24 medical) at Birmingham.

In future years the Grants Committee will present a comparative statement showing the number of new entrants who had previously attended a secondary school for three years or more, and the number who commenced their education in a public elementary school. In a few cases this information is given for $1919-20$ in the separate chapters devoted to the several institutions; thus the College of Technology, Manchester, reports that of 286 full-time students 137 began their education in a public elementary school.

"The increasing demand for Halls of Residence and for more facilities for corporate life," says the Committee in its introduction, "makes it important to show the extent to which provision of the kind is made." Accordingly, Table I classifies students with reference to university residence. Half of them, it appears, lived at home, 37 per cent. in lodgings ( 22 per cent. of the women and 42 per cent. of the men), and II per cent. (4025) in halls of residence, these 
constituting 26 per cent. of the women and only 5 per cent. of the men. These proportions would, of course, be very different if the figures included the students of Oxford, Cambridge, and Trinity College, Dublin. In Wales, Scotland, and Ireland the proportion of students in lodgings is much higher-of those living at home, lowerthan in England. There are good grounds for believing that future returns will show a substantial increase in the proportion of students living in halls of residence. Meanwhile, it may be noted that accommodation of this kind has already been provided for 80 per cent. of its students by Reading University College, for 47 per cent. of their students by the London Women's Colleges, for 36 per cent. by Dublin University College, for 30 per cent. by the University Colleges of Southampton, Aberystwyth, and Bangor, and for 23 per cent. by the University of Bristol.

The total number of full-time students admitted in 1919-20 for the first time for degree and diploma courses is given in Table 2 as 17,381 , of whom rather more than one-fifth were women. They represent half and $3^{8}$ per cent. respectively of the full-time men and women students in the institutions in question. The ages at admission of two-thirds of the men and one-half of the women were nineteen and over; of four-fifths of the men and five-sixths of the women, eighteen and over; while only $35^{2}$ men and 53 women were under seventeen. Of these last-mentioned juvenile entrants Glasgow is responsible for $7 \mathrm{x}$, Birmingham for $5^{1}$, and East London College for 26.

Table 3 gives particulars of part-time students taking courses of university standard. The total number, 15,234 , of whom 23 per cent. were women, includes (a) 10,524 occasional, (b) 2389 diploma, (c) 890 degree, (d) 576 research, and (e) 1055 other post-graduate students. The chief contributors to these totals were :-

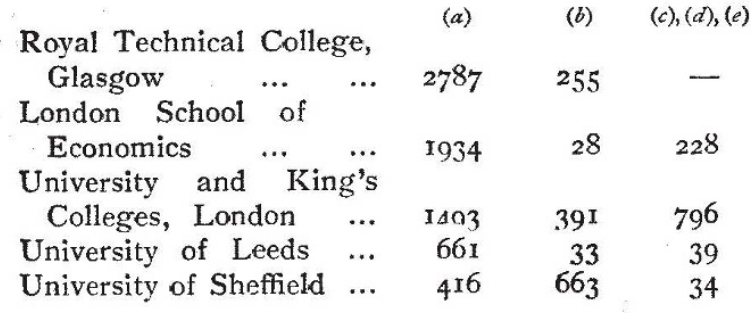

Tutorial classes are organised in co-operation with the Workers' Educational Association by all the universities of England and by those of Wales, Aberdeen, Edinburgh, and Belfast. Particulars given in the several returns show that upwards of 5000 students attended these classes.

Research students were at work in all the institutions figuring in the returns except a few medical schools. Their total number was roog, including 533 full-time students. Women researchers numbered 339 . London institutions had 586 research students, Manchester 133 , Liverpool I26, Birmingham 43. Post-graduate students other than those engaged in research numbered I592, including I055 part-time students. London alone accounts for 869 of these ( 765 part-time). Such data as are available for estimating the number of research and other post-graduate students at work in the university institutions excluded from these tables point to a total of about I 200.

The classification of full-time students by faculties gives the first place to medicine, including dentistry, with 12,657 , including 2949 women. In the faculties of arts, theology, law, music, commerce, economics, and education were II,745, including 5309 women; in pure science, $657 \mathrm{I}$ ( 1538 women); in engineering, applied chemistry, etc., 6ri4 (145 women). Medical and dental students were most numerous in London (3347), Glasgow (1838), Edinburgh (1739), Liverpool (74I), and Aberdeen (704). They outnumbered all other students put together in Belfast and the colleges of the National University of Ireland (in University College, Dublin, they were in a majority of almost 2 to 1 ), and were above 40 per cent. of the total in Glasgow, Aberdeen, and Edinburgh. Corresponding figures for Oxford, Cambridge, and Trinity College, Dublin, are not available. The statistics of degrees and diplomas gained so soon after the war present, of course, abnormal features. The total numbers of recipients were: Of degrees, 4054, including 1275 women; diplomas, 2062 (599 women); degrees according to faculties: arts, theology, law, music, commerce, economics, and education, I666; pure science, ro74; medicine, roo8; engineering, applied chemistry, etc., 306.

Tables 7 and 8 exhibit the Treasury grants, annual and special, made to university institutions for $19^{1} 3^{-14}$, when they amounted to $442,147 l$., and each later year to 1919-20. The annual grants show but few important variations up to 1918-19, but in the following year they were increased, on the whole, by 70 per cent., and amounted to $786,500 l$. Of this, i98,oool. went to London institutions, $260,000 l$. to others in England, 52,50ol. to Wales, $165,000 l$. to Scotland, and I I , oool. to Ireland. The special grants amounted to $104,000 l$. in $1915-16$, 12,00ol. in $1918-19$, and 304,000 . in $1919-20$, in which year special emergency grants pending the reports of the Royal Commissions inquiring into their financial resources were received by Oxford (30,0ool.), Cambridge (3o,oool.), and Trinity College, Dublin (12,oool.). The Civil Service Estimates of March last show $1,000,000 l$. for grants in $1920-2 \mathrm{r}$, and $1,500,000 l$. for grants in 1921-22. A further sum of $500,000 l$. is provided for grants in $192 \mathrm{I}-22$ to the Federated Superannuation Funds for Universities. The principles upon which it is proposed to allocate grants in future are discussed in a report presented by the University Grants Committee on February 3, I92I, a paper which is likely to exercise a farreaching influence on the further development of our universities and their relations with the State. 